Francesco De Toni*

\title{
Expressing friendship in letters: \\ Conventionality and sincerity in the multilingual correspondence of nineteenth-century Catholic churchmen
}

\author{
https://doi.org/10.1515/multi-2018-0133
}

Abstract: The relationship between the polite and conventional nature of friendly language and the sincerity of the writer's feelings is a central topic in linguistic and historical research on friendship in epistolary communication. This relationship can be understood in the context of the emotional values and conventionalised emotional practices that characterise the writer's emotional community.

The language of friendship has a significant role in the history of letter writing in religious communities. However, epistolary and emotional practices among religious groups in the modern era remain a rather unexplored filed of research. In this regard, the nineteenth century is of particular interest, as it saw the consolidation of sincerity as a central notion in European standards of letter writing.

Bringing together historical pragmatics and the history of emotions, this paper describes the forms and functions of sincerity in the negotiation of friendships between nineteenth-century Catholic churchmen. The article analyses a corpus of letters in Italian and Spanish from the multilingual correspondence of European Benedictine missionaries in Australia between the 1850s and the 1890s. The results of the analysis show that sincerity and emotional self-disclosure, while dependent on the pragmatic conventions of letter writing, belonged to cross-linguistic cultural scripts typical of religious communities.

Keywords: historical pragmatics, friendship, sincerity, history of emotions, letter writing

\footnotetext{
*Corresponding author: Francesco De Toni, School of Humanities, The University of Western Australia, 35 Stirling Highway, Crawley, Western Australia 6009, Australia, E-mail: francesco.detoni@uwa.edu.au https://orcid.org/0000-0003-0062-7674
} 


\section{Introduction}

Contemporary Western notions of friendship and sincerity identify the latter as an essential feature of the former. Today, sincerity - defined as the correspondence between inner mental state and outer behaviour - is found in both psychologists' and ordinary people's conceptions of friendship, which is conceived as a mutual, voluntary and intimate relationship (Fehr 1996: 6-16). The association between friendship and sincerity is in fact an ancient one in European culture; however, the meaning of sincerity, the forms and limits of sincere behaviour and the notions of sincere friendship have been subject to diachronic variation (Silver 2003: 123-124). As Williams has observed (2018: 1418; cf. Williams in this volume), this variation can be explained if we regard sincerity as a culturally-embedded ideal, rather than solely as truthfulness of speech dependent on the speaker's psychological state. This ideal has its roots in English as well as in Romance languages - in the meaning of 'purity' of Latin sinceritas and presupposes some cultural moral criterion for the evaluation of the speaker's sincerity of sentiments and motives (cf. Walker 1978). ${ }^{1}$

In the history of epistolary communication, the presence of declarations of friendship, words belonging to the semantic field of friendship or other elements of friendly language (e. g. words denoting affection or non-deferential address pronouns) were not always correlated with the existence of an actual friendship bond between the correspondents (Fitzmaurice 2012; Williams 2013: 165-174). In many historical contexts, the performance of friendship was part of the rhetorical strategies of letter writing and "a matter of using language in an effective way" (Williams 2013: 168). On the other hand, since the notion of sincerity became of particular relevance in early modern and Renaissance Europe (Silver 2003: 125-126; Martin 1997: 103-122), the sincerity of speech acquired novel relevance in epistolary communication and new patterns of sincere language emerged as typical 'rhetoricalities' of epistolary language (Williams 2012: 810, Williams 2010: 171-172).

1 The meaning of 'pure' still belongs to It. sincero and Sp. sincero 'sincere', although it is usually marked as outdated by present-day dictionaries. However, in nineteenth-century dictionaries, 'pure' is indicated as first meaning in both Italian and Spanish (cf. TB and DLC). For Spanish, cf. also the observations by Thomas in this volume. 


\subsection{Historical macro-context: Sincerity in the nineteenth century}

The nineteenth century was a crucial time for the evolution of sincerity, especially in sphere of private relationships. By the beginning of the century, sincerity was commonly recognised as a necessary component of 'true' friendship. According to the entry amicizia 'friendship' in the Italian Nuova enciclopedia popolare, sincerity has to be regarded as the the first law of friendship (" $L a$ sincerità vuol essere considerata la prima legge dell'amicizia"), a statement which is a literal translation from the 1797 edition of the Encyclopædia Britannica and which thus testify to the European scale of the circulation of this notion.

The importance of sincerity is confirmed by nineteenth-century Italian etiquette books, where sincerity emerges as an independent moral category from politeness (Paternoster 2019: 126). At least in Italian, the authenticity of the speaker's intentions and feelings came to be regarded as a condition for the felicity of positive politeness (Paternoster 2015: 263-301), and the epistolary manuals and the conduct books of the time testify to a real obsession with the sincerity of self-expression in letters (Tasca 2002: 150-152, Tasca 2004: 157-165).

\subsection{Object and aims of the study}

Religious communities have proven to be a fertile area of enquiry for the historical study of friendship and sincerity in epistolary correspondence (e. g. Haseldine 1994). Research in the history of emotions has also identified religious communities as typical examples of emotional communities, that is, "groups in which people adhere to the same norms of emotional expression and value - or devalue - the same or related emotions" (Rosenwein 2006: 2). Nonetheless, religious correspondence in the modern era remains a scarcely studied object in historical pragmatics, especially in a multilingual perspective.

The purpose of this study is to describe the pragmatic forms and functions of the language of friendship, of the expression of sincerity and of emotional-self disclosure in the private letters of Catholic churchmen in the nineteenth century. A case study, the analysis focuses on the Italian and Spanish correspondence of the multilingual epistolary networks of New Norcia, a missionary community in Western Australia. The analysis of this correspondence allows the exploration of the above-mentioned pragmatic traits in the private letters of educated men who were not professional writers. Specifically, I will contextualise those traits in the macro-context of nineteenth-century letter writing and in the micro-context of the values and social practices of a religious community. 


\section{Presentation of the corpus}

\subsection{Historical background}

The Catholic Benedictine mission and monastic community of New Norcia was founded in 1846 by the Galician Bishop and monk Rosendo (or Rudesindo) Salvado (1814-1900) with the purpose of evangelising the Aboriginal people in the British colony of Western Australia (Rios 2017: 35-183; Cipollone and Orlandi 2011: 57-232, 467-475). The mission attracted missionaries from various parts of Europe, who belonged to transnational epistolary networks. These networks present a high degree of multilingualism. The nineteenth-century correspondence preserved in the New Norcia Archives include letters in Spanish (45\%), English (44\%), Italian (7\%), French (2\%) and other languages (2\%) (Verdina 2016). Many missionaries wrote in more than one language; in particular, the relatively high percentage of letters in Italian is partially due to the use of Italian as a language of communication within the Catholic Church by non-native speakers (including Salvado).

\subsection{Description of the corpus}

The corpus for the analysis consists of 247 letters selected from Salvado's private correspondence in the years following the foundation of New Norcia. The corpus can be divided into three groups of letters. The first group is constituted by Salvado's correspondence with four Italian Benedictine abbots: Paolo Theodoli (1800-1860), Angelo Pescetelli (1809-1882), Francesco Leopoldo Zelli Jacobuzi (1818-1892), and Michele Morcaldi (1819-1894). The first three were, in chronological order, abbots of the monastery of St Paul's Outside the Walls in Rome, while the latter was the abbot of the Badia di Cava near Salerno (Italy). All four were important figures within the Cassinese Congregation, to which Salvado also belonged; consequently, they could provide significant material, financial and political support to Salvado and his mission. On the other hand, the epistolary exchange with these abbots also served as a means to express personal acquaintances that developed in the context of monastic communal life, as Salvado resided in both monasteries before his departure for Australia and on other subsequent occasions. The surviving correspondence between Salvado and these abbots is all in Italian and consists of 154 letters, from May 18, 1850 to July 29, 1893 (one of Morcaldi's letters has been excluded as it is illegible). All the letters are unpublished and are currently preserved in the New 
Norcia Archives, in the Archives of the monastery of St Paul's Outside the Walls, in the Historical Archives of the Congregation for the Evangelisation of Peoples (Rome), and in the Archives of the Biblioteca Statale of the Monumento Nazionale Badia di Cava (De Toni 2016: 96-99).

The second group of letters included in the corpus are a selection from the correspondence of the Italian Canon Raffaele Martelli (1811-1880) with Salvado. Martelli arrived in Western Australia in 1853. There he spent the rest of his life as a diocesan priest. Although not a monk, Martelli had a strong personal tie with Salvado and the monastic community of New Norcia. His original intentions were to retire to New Norcia after ten years of work as a diocesan priest in Western Australia; however, external circumstances hampered his plans and he was able to reside at New Norcia only for a limited period of time (Kinder and Brown 2014). Martelli's close relationship with Salvado is testified to by the large number of letters in Italian and in English from Martelli to Salvado preserved in the New Norcia Archives (none of Salvado's replies have survived) (Kinder 2010, Kinder 2011). The New Norcia Archives are known to hold 174 letters in Italian from Martelli to Salvado, from March 4, 1853 to April 21, 1864; the letters are still unpublished, but English translations have been published in Kinder and Brown 2014. The correspondence selected for this study is comprised of the forty consecutive letters that Martelli wrote between May 18, 1858 and October 14, 1860.

Finally, the third group of letters is a selection of fifty-three letters from the correspondence between Salvado and the Spanish monk Venancio Garrido (1810-1870). Garrido joined the community and the mission of New Norcia in 1849. He was a close collaborator of Salvado, who regarded Garrido as his own alter ego and appointed him Prior of New Norcia in 1860. The New Norcia Archives hold 238 letters from the correspondence between Salvado and Garrido, from May 10, 1850 to June 17, 1870; all the letters are in Spanish and are unpublished (English translations of Garrido's letters from August 23, 1858 to September 15, 1859 have been published in Keightley 2005). ${ }^{2}$ The fifty-three letters included in the corpus cover the period from April 24, 1858 to November 20, 1863. All the letters of 1859 were written while Garrido was in Ceylon, where he was temporally exiled after some contrasts with José Benito Serra, cofounder of New Norcia and Coadjutor Bishop of Perth. See Table 1 and Figure 1.

The corpus was constructed so that it has a certain degree of social and sociolinguistic homogeneity and, at the same time, allows the study of variation across some variables, namely differences in the hierarchical positions and

2 Unless otherwise indicated, in this study translations of these letters of Garrido's are from Keightley 2005 and translations of Martelli's letters are from Kinder and Brown 2014. 
Table 1: Summary of the correspondence included in the corpus.

\begin{tabular}{|c|c|c|c|}
\hline Sender & Addressee & $\begin{array}{r}\text { Number of } \\
\text { letters }\end{array}$ & Language \\
\hline \multicolumn{4}{|c|}{ Salvado - Theodoli correspondence } \\
\hline Rosendo Salvado & Paolo Theodoli & 15 & Italian \\
\hline Paolo Theodoli & Rosendo Salvado & 14 & Italian \\
\hline \multicolumn{4}{|c|}{ Salvado - Pescetelli correspondence } \\
\hline Rosendo Salvado & Angelo Pescetelli & 54 & Italian \\
\hline Angelo Pescetelli & Rosendo Salvado & 21 & Italian \\
\hline \multicolumn{4}{|c|}{ Salvado - Zelli correspondence } \\
\hline Rosendo Salvado & Francesco Zelli & 20 & Italian \\
\hline Francesco Zelli & Rosendo Salvado & 16 & Italian \\
\hline \multicolumn{4}{|c|}{ Salvado - Morcaldi correspondence } \\
\hline Rosendo Salvado & Michele Morcaldi & 4 & Italian \\
\hline Michele Morcaldi & Rosendo Salvado & 10 & Italian \\
\hline \multicolumn{4}{|c|}{ Salvado - Martelli correspondence } \\
\hline Raffaele Martelli & Rosendo Salvado & 40 & Italian \\
\hline \multicolumn{4}{|c|}{ Salvado - Garrido correspondence } \\
\hline Rosendo Salvado & Venancio Garrido & 22 & Spanish \\
\hline Venancio Garrido & Rosendo Salvado & 31 & Spanish \\
\hline
\end{tabular}

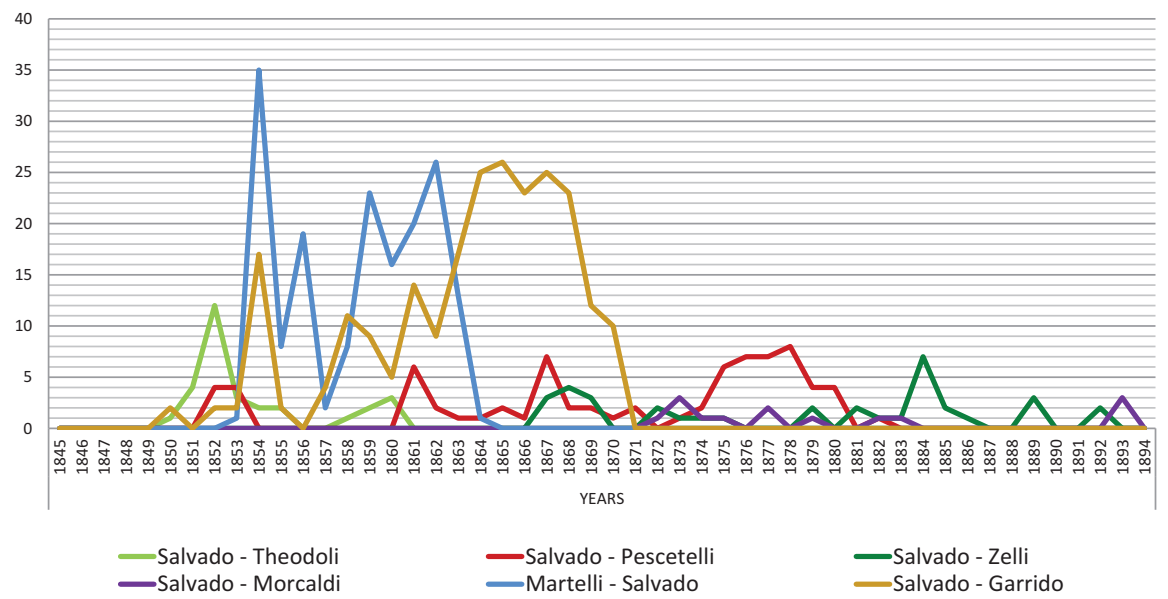

Figure 1: Number of letters exchanged between each pair of correspondents by year (including Martelli's and Garrido's letters not selected for the corpus). 
proximity of the correspondents, and in the language of the letters. All the selected correspondents were educated multilingual churchmen, who had gone through seminary education in Italy and/or Spain. This common educational background guarantees against high diastratic variation between the letters of the corpus. As regards the hierarchical position and proximity of the correspondents, on the one hand we have Salvado's correspondence with the Italian abbots, who were approximately his peers and were not directly involved in the life of New Norcia's community. On the other hand, there is the correspondence with Martelli and Garrido, who occupied a lower position in the Church hierarchy and were part of New Norcia's community or, at least, worked closely with them (the distribution of the correspondents across the discrete parameters of hierarchy and community membership is summarised in Figure 2). Finally, the multilingualism of the New Norcia correspondence is represented through the selection of letters in both Italian and Spanish, with Salvado as the only correspondent writing in two languages. (Salvado's command of the Italian language is described in Verdina 2017) (see Table 1).

\begin{tabular}{|c|c|c|}
\hline 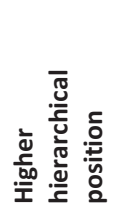 & $\begin{array}{l}\text { Paolo Theodoli } \\
\text { Angelo Pescetelli } \\
\text { Francesco Zelli } \\
\text { Michele Morcaldi }\end{array}$ & Rosendo Salvado \\
\hline \multirow{2}{*}{ 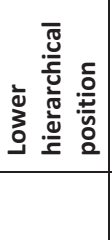 } & & $\begin{array}{l}\text { Raffaele Martelli } \\
\text { Venancio Garrido }\end{array}$ \\
\hline & $\begin{array}{l}\text { Not members of New Norcia's } \\
\text { community }\end{array}$ & $\begin{array}{l}\text { Members of New Norcia's } \\
\text { community }\end{array}$ \\
\hline
\end{tabular}

Figure 2: Hierarchical relationships and proximity between the selected correspondents.

Given that the whole correspondence between Martelli and Salvado and between Salvado and Garrido consists of a large number of letters, only samples of their correspondence were selected. The objective was to balance the number of letters from each pair of correspondents in the corpus. The two samples were chosen from similar time periods (overall, between 1858 and 1863) and in relatively similar amounts. The period was chosen because it belongs to a mature phase in the relationships between the correspondents (who had already 
lived in Western Australia for some years) and also includes the years of Garrido's exile to Ceylon (a particularly challenging moment in his missionary experience).

\section{Methodology}

The linguistic analysis of the letters is qualitative and adopts a lexical approach. Firstly, the study describes the formulaic and rhetorical functions of the vocabularies of friendship and sincerity in the letters (Sections from 4.1 to 4.4). The analysis of the vocabulary of friendship focuses on the lexical families of It. amico and Sp. amigo 'friend'. The analysis of the vocabulary of sincerity, on the other hand, considers a broader range of sincerity markers that belong to the semantic fields of sincerity and truthfulness. Secondly, the study presents some patterns of emotional self-disclosure by focusing on instances of emotion talk that express the letter writers' emotional experience (Section 4.4; with emotion talk I mean terms and phrases - including lexicalised figurative ones - denoting an emotion; cf. Bednarek 2008: 10-11). The identification and categorisation of emotion words was based on a multilingual list of 112 words compiled from psycholinguistic studies (Scherer 2005, Scherer 1988; Galati et al. 2008). Each word of the list was translated into Italian, Spanish and English and adopted as a category to identify and group emotion words that are synonyms or semantically affine or associate (these categories are written in SMALL CAPS in English).

\section{Analysis}

\subsection{Formulaic expression of friendship and social hierarchy}

In nineteenth-century Italian, amico was a frequent social-deictic term in the epistolary formulae of educated people's private correspondence, and it could refer both to the addressee of the letter (in introductory formulae, i. e. the formulae that open the letter) and to the sender (in end formulae, i. e. the formulae that close the letter). The word was not restricted to the correspondence between intimates and could be used in letters addressed to simple acquaintances (Antonelli 2003: 53-62). According to the entry amico in Tommaseo and Bellini's Dizionario della lingua italiana (TB), amico in the introductory and end formulae of familiar correspondence was so common 
that it almost had no meaning. The consolidation of its use in the nineteenth century followed a period of expansion during the previous century, that is, the years in which the private letter started to emerge as a codified genre for frequent communication among the educated members of society (Betri \& Maldini Chiarito 2000: 8). For instance, in the letters of the eighteenth-century men of letters Pietro and Alessandro Verri, not only the lexical family of amico is regularly found in introductory and end formulae, but also the notion of amicizia 'friendship' is often invoked and thematised in the body of the letters (Guidolin 2011: 543-546). In a similar way, the Spanish amigo had been part of the formulaic vocabulary of Spanish familiar letters since at least the eighteenth century, when it replaced early modern courteous expressions of discernment (Castillo Gómez 2011: 31-32).

Thus, if we regard friendship as an intimate bond and sincerity as psychological truthfulness, the presence of the lexical families of amico and amigo in introductory and end formulae cannot be considered by itself an indicator of a sincere or authentic friendship between the correspondents. Nonetheless, differences in the social positions of the correspondents are correlated with differences in the use of the vocabulary of friendship. Amico as a deictic term referring to either the addressee or the sender or explicit references to friendship bonds between the correspondents are found only in the letters written by Salvado and by the Italian abbots, in both introductory and end formulae; on the other hand, amigo is only found in the end formulae of Salvado's letters to Garrido (see Figure 3). With the exception of Theodoli's letters, when amico is used in introductory formulae, the most frequent choice is a double formula, which first addresses the recipient with his honorifics and only in the following line as amico:

(1a) Stmo [Stimatissimo] Mo. [Monsignore] ed Amico ${ }^{3}$

'Most esteemed Monsignor and friend'

(P. Theodoli to R. Salvado, 29 November 1851, New Norcia Archives [NNA] 2234A-6-83)

(1b) Illm[ ]o [Illustrissimo] Rdm[ ]o [Reverendissimo] Monsignore | Carissimo Padre ed Amico

'Most illustrious and reverend Monsignor, very dear Father and friend'

(M. Morcaldi to R. Salvado, 29 November 1873, NNA, 2234A-28-112)

3 In the transcriptions, abbreviations in the manuscripts are followed by the full forms of the abbreviated words between square brackets. If the abbreviation is marked by a tilde or another sign with the same function, the tilde sign ' $\sim$ ' is added between square brackets after the letter over which the tilde is in the manuscript. The end of the line is represented by a bar 'l'. 


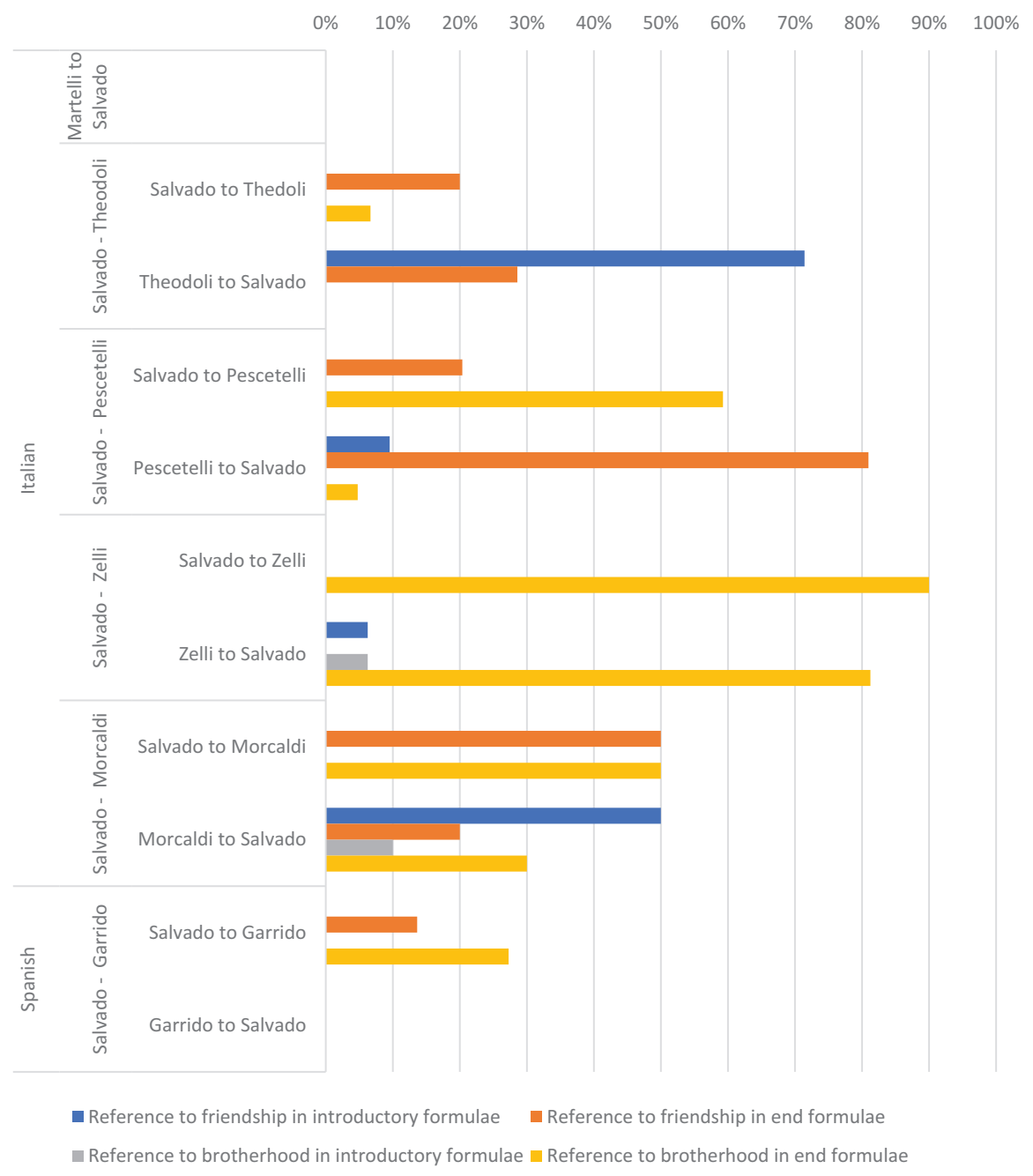

Figure 3: Distribution of words referring to friendship (amico, amicizia, amigo or amistad) and brotherhood (confratello or hermano) between the correspondents.

In end formulae, amico is one of three possible deictic nouns for the recipient that we find in the whole Italian part of the corpus, the other two being servo 'servant' and confratello 'monastic brother/confrere' (most frequent in the correspondence between Salvado and Zelli, where amico is scarcely used). In fact, when amico is not used by itself, it is paired in coordination with either servo or confratello. 
(2a) Vi abbraccio e mi confermo $\mid V^{\circ}$ affm[ ]o [affezionatissimo] Amico 'I hug you and I confirm myself | your most affectionate friend' (A. Pescetelli to R. Salvado, 18 January 1868, NNA, 2234A-23-258)

(2b) Ci raccomandi assai al Signo-|re, e in mezzo alla selva Australiana sia per-|suaso ha sempre un confratello che | abbracciandola strettamente ha l'onore di rispettarsi | Suo Affm[ ]o [Affezionatissimo] amico e servo 'Strongly recommend us to the Lord and be persuaded that, in the Australian forest, you will always have a confrere, who, hugging you tightly, has the honour of professing himself Your most affectionate friend and servant'

(R. Salvado to A. Pescetelli, 13 April 1853, Archives of the abbey of St Paul's Outside the Walls [ASP], series Congreg. Cassinese, 14C, volume 'Salvado-Nuova Norcia')

The collocation of amico and servo (or the synonym servitore) is typical of Italian nineteenth-century familiar letters; this is confirmed by both Antonelli (2003: 61-62) and by the interrogation of the CEOD (the digital corpus of nineteenthcentury letters in Italian), where we find eight tokens of servo ed amico. Finally, in some end formulae, instead of the deictic noun amico we find references to amicizia, which is either requested from or declared to the recipient (no tokens of Sp. amistad 'friendship' were found in end formulae); see (3).

(3) Preghi per me, mentre in tutto | il rispetto, ed Amicizia, mi rassegno | di Lei Stimo [Stimatissimo] Mo. [Monsignore] | Umo [Umilissimo] Demo [Devotissimo] Obbmo [Obbedientissimo] Servo

'Pray for me, while with all respect and friendship, I remain, most esteemed Monsignor, Your most humble, devoted and obliged servant'

(P. Theodoli to R. Salvado, sine die January 1859, NNA, 2234A-14-014)

The use of the vocabulary of friendship between peers and from superiors to inferiors was probably limited by the availability of the terms confratello and hermano 'monastic brother/confrere', which offered an alternative way to define the intimate social bonds between the correspondents in the religious community. With the exception of Theodoli's letters, reference to monastic brotherhood is indeed found across the correspondence between the abbots (mainly in end formulae) and in Salvado's letters to Garrido.

On the other hand, in Martelli's and Garrido's letters, no explicit reference to friendship is found in introductory or end formulae, an asymmetry that is a continuation of social practices already in place in the eighteenth century, whereby "it 
was the person of higher rank who was a friend to the other, rather than the reverse" (Garrioch 2014: 193). Both Martelli and Garrido always address Salvado with one or more honorific titles in their introductory formulae (It. Monsignore and Sp. Monseñor 'Monsignor'; Sp. Señor 'Lord'), and, in their end formulae, refer to themselves only as It. servo and Sp. servidor 'servant' and/or Sp. capellán 'chaplain'. However, in their end formulae as well as in the body of their letters, they both send salutations to other amici and amigos in the community and refer to them as communal friends (e.g. It. $i$ nostri amici 'our friends').

\subsection{Formulaic expression of sincerity}

In the letters in Italian, the lexical family of sincerità 'sincerity' has limited frequency and restricted use in epistolary formulae. Apart from one token in Martelli's letters and two in Zelli's, all the other instances are found in the end formulae of Salvado's letters to the Italian abbots. In the closings of these letters, the adjective sincero 'sincere', the adverb sinceramente 'sincerely' and the noun sincerità refer to either Salvado's feelings (esteem, gratitude, affection, etc.; 4a) or to Salvado's friendship and brotherhood with the addressee (4b and 4c).

(4a) Mi perdoni e mi creda con sincera stima | Devmo [Devotissimo] e Obbm[ ]o [Obbligatissimo] confratello

'Forgive me and believe me to be, with sincere esteem, most devoted and most obliged confrere'

(R. Salvado to A. Pescetelli, 30 July 1867, ASP, Congreg. Cassinese, 14C, 'Salvado-Nuova Norcia')

(4b) mi creda colla più | sincera e cordiale amicizia suo | Dm[ ]o [Devotissimo] e Affm[ ]o [Affezionatissimo] confratello

'believe me to be, with the most sincere and cordial friendship, Your most devoted and most affectionate confrere'

(R. Salvado to F. Zelli, 19 September 1867, ASP, Congreg. Cassinese 14C, 'Mons. Salvado apostolo dell'Australia')

(4c) e voi credetemi sinceramente | vostro affmo [affezionatissimo] amico vero 'and you believe me to sincerely be your most affectionate true friend' (R. Salvado to M. Morcaldi, 4 October 1873, Archives of the Biblioteca Statale of the Monumento Nazionale Badia di Cava [AMC], armarium D, 4.1) 
As the last example shows, Salvado also marks the genuineness of his declared relationship with the addressee with the adjective vero 'true', which is more frequent than sincero and is collocated with amico as well as with servo and confratello. Vero is also frequently collocated with the same three nouns in the letters of the four Italian abbots. These formulaic traits agree with the common practices of nineteenth-century private correspondence: in the end formulae of the $C E O D$, we find 22 tokens of the lexical family of sincerità in end formulae, most frequently collocated with affetto 'affection', but also with amicizia; on the other hand, we have 59 instances of amic-o/- $a$ ver-o/- $a$ or ver-o/-a amic-o/-a 'true friend'.

In the Spanish correspondence the lexical family of sinceridad 'sincerity' is absent in end formulae. However, in Garrido's letters, we have the occasional use of the expression seguro servidor 'sure servant'; this expression is also typical of correspondence, as it is confirmed by the 22 tokens of segur-o/- $a$ servedor/- $a$ in the CORDE (the diachronic corpus of the Spanish language; theme: letters and reports; period: 1800-1900; area: Spain). These observations agree with Thomas' findings (in this volume) and support the hypothesis that the preference for the lexical family of seguridad 'certainty' over that of sinceridad was a distinctive trait of nineteenth-century Spanish epistolary language.

\subsection{The lexical family of the heart as a sincerity marker}

The association between the heart and sincerity is identified by nineteenthcentury lexicographic resources. According to the entry cuore 'heart' in the TB:

When, instead of the person, one mentions the heart [It. cuore], the affection that one intends to mean is felt as more sincere [It. sincero] and deep. To say my heart rejoices is much more than saying I rejoice (translation mine).

Such a specific reference to sincerity does not appear in the entry corazón 'heart' of the Real Academia Española's Diccionario de la lengua castellana (DLC); however, the entry confirms the synonymity of the heart with inner feelings and, more specifically, with love and affection.

In the New Norcia correspondence, terms belonging to the lexical families of the heart in Italian and Spanish are frequent markers of sincerity and the use of the heart as a metonymy for the speaker's faculty of feeling is found across all the letters. Both the $T B$ and the $D L C$ also lists examples of terms and phrases pertaining the heart which work as lexicalised markers on sincerity. In the letters 
of the corpus, we find three main groups of terms belonging to the lexical families of cuore and corazón that act as sincerity markers:

- prepositional phrases with cuore (It.) and corazón (Sp.) (e.g. col cuore 'from one's heart');

- the adverb cordialmente (It.) 'cordially';

- the adjectives cordiale (It.) and cordial (Sp.) 'cordial'.

In nineteenth-century correspondence, these terms are relatively frequent (in Italian letters, they are more frequent than those belonging to lexical family of sincerità). In the CEOD and in the CORDE (letters and reports; 1800-1900; Spain) we find the following numbers of tokens: It. di cuore, 220; It. col cuore, 18; It. cordiale, 71; It. cordialmente, 32; Sp. de corazón, 21; Sp. cordial, 18. While both the $T B$ and the $D L C$ confirm that these terms have a connotation of affection, their use in expressive speech acts is strongly formulaic and similar to that of markers belonging to the lexical families of sincerity (with which they are coordinated in a few instances).

(5a) Poche linee per augurarle un felice viaggio e per congratularmi di cuore per la doppia vittoria

'Few lines to wish You a happy trip and warmly congratulate you on the double victory'

(R. Martelli to R. Salvado, 27 November 1861, NNA, 2234A-16-139)

(5b) Mi cordiales afectos, a los $P P .^{s}$ [padres] y hermanos

'My cordial greetings to the fathers and confreres'

(V. Garrido to R. Salvado, 25 August 1859, NNA, 2234A-14-086)

As the examples show, these markers are employed within speech acts of thanking, greeting and congratulating, but they seldom co-occur with terms that explicitly denote emotions (on collocation of sincerity markers with expressive speech acts cf. Tamošiūnaitè in this volume). Furthermore, although these sincerity markers are found in all the letters of the corpus (more frequently in Italian than in Spanish), their collocations differ. In fact, their use in utterances where the connotation of affection is more marked is limited to the correspondence between peers. For instance, in the correspondence between Salvado and the abbots we often encounter salutations constructed on the model of abbracciare di cuore 'to hug with one's heart', which is a typical formula of private correspondence between family members (Abbatelli 2009: 81). 


\subsection{Friendship, sincerity and truthfulness: Rhetorical functions}

In Salvado's letters to the Italian abbots, the vocabularies of friendship and sincerity are employed as rhetorical devices within arguments. A clear example is provided by one of Salvado's letters to Abbott Theodoli. In the 1850s Salvado was in bad terms with the already mentioned José Serra, who, as Administrator of the diocese of Perth, was engaged in a political battle with Salvado for the control over New Norcia. Salvado sought help from Abbot Theodoli, who could intercede for him with the Congregation for the Propagation of the Faith in Rome (the Congregation oversaw all the missions of the Catholic Church). In the opening of the letter, friendship is rhetorically invoked as the basis for political support:

(6a) Dunque non vi sono più speranze per me di ricevere | una lettera del mio amico e benefattore l'Abbate Theodoli! Ma perché? | Cosa è avvenuta di così grave carattere in me, da non più meritare un | tanto favore?

'Then there is no hope for me to receive a letter from my friend and benefactor Abbot Theodoli! But why? What has happened of such a bad character in me that I no longer deserve so much favour?'

(R. Salvado to P. Theodoli, 10 July 1860, Historical Archives of the Congregation for the Evangelisation of the Peoples or de Propaganda Fide [APF], fondo Scritture riferite nei Congressi [SC], series Oceania, 6, f. 1192r)

In the rest of the letter, references to friendship and sincerity are used jointly. Both Salvado and his contender Serra had personal relationships with Theodoli. Thus, Salvado was aware that Theodoli would naturally be led to believe Serra's claims on the basis of the friendship bond that Theodoli himself and Serra had; see (6b). Consequently, Salvado also had to reassert his friendship with Theodoli as a means to give moral grounding to his assertions; see (6c).

(6b) pare li senta dirmi [...] mi pare impossibile | non credere ad uno che ragiona come faceva colui che alla sera a $\mid$ me accanto mi raccontava con sincerità d'amico la propria ed altrui | storia

'I can imagine you telling me [...] "it seems impossible not to believe a person [Serra] who argues in the same way as who, next to me in the evening, used to tell me his and other people's story with the sincerity of a friend"'

(R. Salvado to P. Theodoli, 10 July 1860, APF, SC, Oceania, 6, f. 1192r) 
(6c) Dunque P. [Padre] Abbate mio non mi voglia privare della di Lei | amicizia e siane certo che se mi danno opportunità potrò convin-|cerli viemaggiormente della mia sincerità e dell'essere ora l'istesso | stessissimo di prima 'Thus, my Father Abbot, may you not want to deprive me of Your friendship and be assured that, if they give me the chance, I will be able to convince them even more of my sincerity and of me being the same, the very same as before'

(R. Salvado to P. Theodoli, 10 July 1860, APF, SC, Oceania, 6, f. 1193r)

We can interpret this pragmatic use of words denoting friendship and sincerity through the notion of sincerity condition. According to Searle (1969: 54-71), sincerity is one of the four types of felicity conditions required for the successful performance of a speech act. In Salvado's letters to his Italian friends, this condition becomes particularly important. Because of the geographical distance separating the correspondents, the sincerity condition needs to be soundly established so that the letter can be an effective substitute of face-to-face interaction. However, I agree with Williams (2018: 24) that Searle's definition of the sincerity condition is incongruent with sincerity as a historically- and culturally-embedded ideal. As Williams points out, Searle's sincerity condition is about "mean-making in communication". It deals with variation in pragmatic meaning on the basis of the presence or lack of consistency between the propositional content and the psychological state specified in the sincerity condition itself; it explains lying and irony, but it does not apply to every kind of speech acts (e.g. greetings; cf. Searle 1969: 65). Affectivity is not a central concern of Searle's sincerity condition. On the other hand, sentiment and motives as well as their moral evaluation are at the core of the notion of sincerity as a cultural ideal. Thus, I reappropriate the notion of sincerity condition as a felicity condition that is still necessary for the successful performance of the speech act, but that relies on an ideal of sincerity dependent on a specific cultural framework and moral values. In the example here considered, the underlying assumption which Salvado and Theodoli are supposed to share is that sincerity is an essential and desirable component of friendship; thus, the existence of a friendship bond guarantees the felicity of the speech act. Specifically, the sincerity condition guarantees that the speech originates from morally sound motives and sentiments rather than from deception or other bad intentions (cf. Walker 1978: 494-496).

Furthermore, Salvado's speech acts are not simple assertions; they are standpoints supported by an argumentation. Thus, the sincerity condition overlaps with what Eemeren \& Grootendorst (1992: 30-33) have called 'responsibility 
conditions' (the speaker believes in his standpoint and that his argumentation is acceptable). In this context, the simulation of sincerity and friendship can be a rhetorical strategy to achieve the perlocutionary act of persuading the hearer. After (6b), while referring to Serra, Salvado admits that "it seems impossible not to believe certain people, [...] because of the eloquent persuasiveness with which God endowed them" (sembra impossibile il poter negar fede | a certe persone [...] per la eloquente persuasiva di | cui Iddio li ha dottato, R. Salvado to P. Theodoli, July 10, 1860, PF, SC, Oceania, 6, f. 1192r). Against Serra's eloquence, Salvado repeatedly asserts that his argumentation is grounded in reality, unlike Serra's. Specifically, Serra's claims are castelli nell'aria 'castles in the air' (i. e. 'fantasies'; three tokens in the letter plus one token of castello [...] fabbriato nell'aria 'castle built in the air' and one token of the metonymy tetto nell'aria 'roof in the air') and belli ideali 'nice ideals' or a bello ideale 'nice ideal' (four tokens overall, always with irony). On the other hand, Salvado's argument is based on fatti positivi 'positive facts', a phrase that Salvado employs seven times in the letter and is reinforced by the repeated employment of the adverbs and adverbial expressions in vero 'in truth' (six tokens), in rialità 'actually' (two tokens), rialmente 'actually'/'truly' (three tokens with adversative meaning; seven tokens as upscalers, one of which with irony). This adherence to reality - which is implied to be a desirable disposition in the correspondents' shared moral axiology - is presented by Salvado as a trait of his character; immediately after (6c) he adds:

(7) A me pare che se manco è per essere troppo | positivo nelle mie cose e fatti; fare castelli nell'aria non va col | mio carattere e né farli né scriverli né dirli. Quando scrivo una | cosa grave e seria domando prima alla coscienza se essa è oppure | no soddisfatta onde non avermene a pentire dopo [...]; la verità è il mio norte.

'It seems to me that, if I fail, it is because I am too positive in my things and facts; building castles in the air does not agree with my character; building them, writing them or saying them does not agree with my character. When I write something grave and serious, I always ask to my conscience, in advance, whether it is satisfied or not, so that I will not regret it later; truth is my North.'

(R. Salvado to P. Theodoli, 10 July 1860, APF, SC Oceania, 6, f. 1193r)

This rhetorical move aims at satisfying the sincerity and responsibility conditions of the argument: specifically, it asserts the speaker's belief in the acceptability of the utterances supporting his standpoint. However, rather than relying on declarations of sincerity, this belief is supported by declarations of truthfulness (i. e. 
agreement between utterances and reality), which aim to give objective validity to the speaker's standpoint. The ontological and moral superiority of truthfulness over sincerity and the circulation of this notion in different European languages is confirmed by the words of the Italian lexicographer Niccolò Tommaseo, who expands a similar definition in French from Faure's 1819 Nouveaux synonymes français a l'usage des jeunes demoiselles:

Truthfulness [It. veracità] is the conformity between words with facts as we see them or as they are; sincerity [It. sincerità] is the conformity between feeling and intentions with words and actions. Sincerity is a kind of truth; but the latter is a much more general idea. It is not sufficient to be sincere in order to be truthful; it is necessary that I say the truth as it is; i. e. that I can understand the truth and express it.

(Tommaseo 1867: 460; translation and emphasis mine)

\subsection{Emotion talk}

The discussion presented in the previous section highlights the ideal nature of sincerity, which depends on shared cultural values. However, this culturallyembedded and interactional ideal does not exclude - and actually encompasses the conceptualisation of sincerity as a psychological truthfulness (i. e. correspondence between outward behaviour and inner state of mind; cf. Walker 1978: 494495). As this notion of sincerity is regarded as a desirable trait of the present-day as well as the nineteenth-century concepts of friendship, we wonder whether and how it was demonstrated in the epistolary discourse. The formulaic and rhetorical use of the vocabulary of friendship and of sincerity markers suggests that the sincere expression of feelings and the construction of friendships could not and, in fact, did not rely on explicit declarations of sincere behaviour and were independent from expressions of deference. In contrast, in the New Norcia letters the authenticity of feelings and of personal relationships appears to stem from patterns of emotional self-disclosure between the correspondents. In this regard, particularly interesting are Martelli's letters to Salvado and the correspondence between Salvado and Garrido. Although Martelli and Garrido were not peers of Salvado in terms of ecclesiastical hierarchy, they shared with him years of communal missionary and monastic life in Australia. This shared dedication to New Norcia and its mission is a characteristic theme of self-disclosure in their letters.

In Martelli's letters, almost half of the tokens of emotion words belong to the semantic fields of HOPE, PLEASURE/ENJOYMENT and DESIRE. These three groups make, respectively, some $18 \%, 14 \%$ and $14 \%$ of the total number of tokens found: 
HOPE: sperare, V; speranza, N.

PlEASURE: diletto, N; dolce, N; esser grato, Adj; far bene al cuore, V; fare piacere, V; godere, V; godimento, N; grato, Adj; lieto, Adj; piacere, V; piacevole, Adj; rallegrarsi, $\mathrm{V}$.

DESIRE: bramare, V; bramoso, Adj; desiderabile, Adj; desiderare, V; desiderato, Past part.; desiderio, N.

The verbs and nouns in HOPE and DESIRE introduce what we can call 'projection structures', that is, functional and grammatical structures that express "not a direct representation of (non-linguistic) experience" but "representation of a (linguistic) representation", which is quoted or reported (Halliday and Matthiessen 2004: 441). These structures are indicators of involvement, which

not only express the author's point of view, but construct a recipient. [...] They anticipate reactions and seek to elicit certain responses, thus contributing to the interactive nature of the letters and helping to strengthen the relationships those letters embody (Moreton 2015: 278).

I here refer to projection structures in a broader sense than Halliday and Matthiessen's. In fact, I refer to projections structures that are introduced not only by verbs, but also by nouns and adjectives; furthermore, the projected element is not necessarily a clause, but it can also be a noun (which could be expanded into a clause with a verb and a direct object; see $8 \mathrm{a}$ ) or it can be implied (inferred from the context; see 8c).

When the emotion is directed, emotion terms denoting HOPE and DESIRE in Martelli's letters introduce projections of proposals, that is, "exchanges of goods-\&-services" (i. e. exchanges that require a non-verbal response, such as offers) which are "projected mentally by processes of desire", rather than "exchanges of information" (Halliday and Matthiessen 2004: 461; cf. Moreton 2015: 282). The analysis of the triggers of these projections shows the presence of some recurrent and frequent themes, which all refer to the personal relationship between Martelli and Salvado. Specifically, triggers of HOPE and DESIRE are often Martelli's prospect of meeting Salvado or other shared friends, Martelli receiving correspondence from Salvado or other friends, and Martelli visiting or joining the community of New Norcia.

(8a) Comunque sia | posso almeno sperare il regalo | di una visita, in fretta in fretta?

'Whatever the case, can I at least hope for the gift of a visit [of Salvado's], in haste?'

(R. Martelli to R. Salvado, 28 March 1859, NNA, 2234A-14-048) 
(8b) L'anniversario prossimo, spero, mi troverà | vicino a Lei in Nova-Norcia 'The next anniversary, I hope, You will find me close to you in New Norcia' (R. Martelli to R. Salvado, 24 October 1859, NNA, 2234A-15-283 and 2234A-22385; translation mine)

(8c) Povero me! In luogo di avvi-|cinarmi allo adempimento del mio deside-|rio, me ne vedo sempre più lontano. | E quando giungerà per me il dì che po-|trò dire in N. Norcia: Haec est domus mea: | hic habitabo, quoniam elegi eam? 'Poor me! Instead of getting closer to my desire [of moving to New Norcia], I am getting further away from it. And when will the day come for me when I will be able to say in New Norcia: "This is my home: here I dwell, for I have chosen it" [in Latin]'

(R. Martelli to R. Salvado, 26 July 1860, NNA, 2234A-15-239)

These same triggers are also recurrent with emotion terms expressing PLEASURE/ ENJOYMENT, including instances in which the emotion term is negated:

(9a) Benché brevi, le sue lettere mi fanno | bene al cuore. Al cuore! Ella dirà. Sì, al cuore | che spesso è posseduto da foschi pensieri e da | sinistri presentimenti 'Although brief, Your letters are good for my heart. "Your heart!”, You will say. Yes, my heart, which is often possessed by dark thoughts and sinister forebodings'

(R. Martelli to R. Salvado, 28 July 1858, NNA, 2234A-13-363)

(9b) I campi | di N. Norcia, mi figuro, verdeggiano: | ma il goderne la vista, non è più | un piacere per me

'The fields of New Norcia, I imagine, are turning green; but enjoying the sight of them is no longer a source of pleasure for me'

(R. Martelli to R. Salvado, 19 July 1858, NNA, 2234A-13-358)

Physical separation and dedication to the mission are also recurrent triggers of emotion talk in the correspondence between Garrido and Salvado. In particular, in the letters of Garrido's exile in Ceylon, we find repeated expressions of emotions that employ corazón as a metonymy for the speaker's feelings within metaphorical expressions.

(10a) Esta es bien pequeña diferencia para | los que se aman de veras en el Señor, | de los quales dice S. Bernardo "que I no estan menos donde ama[ ]n, que donde | animan" lo que seria lo mismo que | decir a U. Illm[ ] a y a la Mission Be-|nedictina de Nueva Nursia que | mi corazon se queda aqui, mi cuerpo | 
unicamente es obligado a dejarse | de la playas de la Australia

'There is very little difference for those who truly love each other in God, about whom St Bernard says that they are not less where they love than where they live; which is the same as to tell Your Grace and the Benedictine Mission of New Norcia that my heart stays here, and only my body is forced to leave the beaches of Australia'

(V. Garrido to R. Salvado, 28 July 1858, NNA, 2234A-13-094)

(10b) Acaso por al-|guna desconfianza en su Omnipoten-|cia, no haciendome cargo que era sola-|mente obra suya, me a juzgado indig-|no de hacer parte de esa mision, la que | à pesar de todo no la puedo alejar de | la mente y del corazon 'Perhaps through some lack of trust in His omnipotence, by not coming to terms with the fact that I am entirely His work, He has judged me unworthy of sharing in that Mission, which despite all I cannot distance from my mind and heart'

(V. Garrido to R. Salvado, 1 May 1859, NNA, 2234A-14-036)

In particular, in (10a) the pragmatic meaning of the metaphor mi corzón se queda aquí 'my heart stays here' is clarified by the presence of the emotion term aman 'they love'. Specifically, the love between the correspondents is implied to be a form of religious love, which exists because both correspondents also love God and which is supported by the example of religious men of the past (cf. Bernard of Clairvaux, Liber de praecepto et dispensatione, cap. 20, n. 60: Neque enim praesentior spiritus noster est ubi animat, quam ubi amat 'In fact, our soul is not more present where it lives than where it loves').

The same identification of New Norcia as the metaphorical place of the heart as expressed in (10a) and (10b), is also found in Martelli's correspondence:

(11) Il corpo è tornato al suo posto, ma | il cuore l'ho lasciato a Vittoria Plains 'My body has returned to its place, by I left my heart in Victoria Plains [the shire where New Norcia is located]'

(R. Martelli to R. Salvado, 14 October 1859, NNA, 2234A-15-268 and 15-128)

However, hierarchical asymmetry also infiltrates in the use of emotion talk. This is the case with emotion words denoting LOVE for the correspondent or his community in a literal way. First-person declaration of LOVE that use nonfigurative terms of LOVE are only directed from peers to peers (and, indirectly, to the community they led). Most interestingly, such declarations of LOVE can even be directed to unknown peers in the addressee's community, on the basis of the bond of monastic brotherhood; see (12). 
(12) y sobre todo presente mis mas respetuosos obsequios a ese dignisimo $S^{r}$ [señor] | Obispo Bravi al que aunque no tengo el honor de conocer personalmente | amo como a hermano

'and, above all, present my most respectful regards to that most worthy Bishop Bravi, whom, although I do not have the honour of knowing him personally, I love as a confrere'

(R. Salvado to V. Garrido, 27 December 1858, NNA, 2234A-13-125)

\section{Conclusions}

The analysis of the New Norcia correspondence shows that the use of the vocabulary of friendship as well as words working as markers of sincerity was heavily dependent on nineteenth-century epistolary norms. The letters present typical pragmatic traits of polite epistolary conversation among nineteenth-century educated correspondents. In particular, Salvado's correspondence with the Italian abbots, which was instrumental in exchanging administrative information and requesting support for the mission, has two common pragmatic features of nineteenth-century business letters: 1) the formulaic and rhetorical use of friendly language and the infiltration of affectivity (Del Lungo Camiciotti 2006, Del Lungo Camiciotti 2012; Poublan 1991: 397-400); 2) the use of markers of trust and "an idea of reliability that derives from objectivity" (Dossena 2010: 199).

Variations in the use of friendship and sincerity vocabularies and the analysis of emotion talk highlight the dependence of the pragmatics of friendship and sincerity on the hierarchical structure of the Church and, at the same time, the shared experience of missionary life. In the upper levels of the hierarchy, personal friendships between abbots also meant political ties between monasteries. Thus, references to friendship and sincerity contributed to the felicity of speech acts in arguments, making a political use of friendly or affective language that is not isolated in monastic emotional communities (Rosenwein 2010).

On the other hand, variation in the use of deictic friendship terms and sincerity markers between correspondents of different status suggests the persistence, within the ecclesiastical environment, of a system of discernment (cf. Kádár and Mills 2013: 143), which limited the writers' agency in their pragmatic choices. ${ }^{4}$ However, the presence of hierarchical differences did not prevent the expression of emotional self-disclosure in a way that matches the present-day

4 According to Kádár and Mills's definition, discernment is a system of "socially dominant norms of relationally constructive conventional and ritualistic behaviour”, including linguistic behaviour. 
notion of sincere friendship. The use of emotion words and tropes denoting affection towards the mission and its community, including superiors, suggests the presence of an emotional community made up by the men who were personally involved in the life of the mission.

Finally, we observe that the pragmatic phenomena analysed are scarcely affected by cross-linguistic variation, the only noteworthy exception being the absence of the lexical family of sinceridad in Spanish end formulae. Sociopragmatic homogeneity and variation across the different pairs of correspondents appear to be primarily due to macro-contextual and micro-contextual causes (i. e. the conventions of private epistolary correspondence and the specific sociocultural traits of the ecclesiastical environment), which crossed the boundaries between European languages.

Acknowledgements: This research was supported by an Australian Government Research Training Program (RTP) Scholarship and by the Australian Research Council Centre of Excellence for the History of Emotions, 1100-1800 (CE110001011). I am thankful to Associate Professor John Kinder and to Associate Professor Jacqueline Van Gent for supervising my research. I am also thankful to Dr Joshua Brown and Dr Federica Verdina for allowing me to view their transcriptions of some of the archival documents analysed in this study. Finally, I am grateful to all the archivists at the archives that hold the documents analysed in this study.

\section{References}

Abbatelli, Valentina. 2009. La semantica dell'affettività nel carteggio della famiglia Tondi da Viterbo. In Giuseppe Antonelli, Massumo Palermo, Danilo Poggiogalli, Lucia Raffaelli \& Giorgio Pozzi (eds.), La scrittura epistolare nell'Ottocento: Nuovi sondaggi sulle lettere del CEOD, 73-82. Ravenna: Pozzi.

Antonelli, Giuseppe. 2003. Tipologia del genere epistolare nel primo Ottocento: Sondaggi sulle lettere familiari di mittenti cólti. Roma: Edizioni dell'Ateneo.

Bednarek, Monika. 2008. Emotion talk across corpora. Basingstoke, England \& New York: Palgrave Macmillan.

Betri, Maria Luisa \& Daniela Maldini Chiarito. 2000. Introduzione. In Maria Luisa Betri \& Daniela Maldini Chiarito (eds.), "Dolce dono graditissimo": La lettera privata dal Settecento al Novecento, 7-17. Milano: Franco Angeli.

Castillo Gómez, Antonio. 2011. "Me alegraré que al recibo de ésta ... ": Cuatrocientos años de prácticas epistolares (siglos XVI a XIX). Manuscrits: Revista d'Història Moderna 29. 19-50.

$C E O D=$ Corpus Epistolare Ottocentesco Digitale. http://ceod.unistrasi.it (accessed 23 November 2018). 
Cipollone, Giulio \& Clara Orlandi. 2011. Aborigeno con gli aborigeni: Per l'evangelizzazione in Australia: Il testo della Relazione per Propaganda Fide del vescovo Rudesindo Salvado. Città del Vaticano: Libreria Editrice Vaticana.

CORDE = Real Academia Española. Corpus Diacrónico del Español. http://corpus.rae.es/corde net.html (accessed 23 November 2018).

De Toni, Francsco. 2016. Constructing friendship with letters: Some observation on friendship and its linguistic expression in the correspondence of Rosendo Salvado's epistolary networks. New Norcia Studies 23. 93-108.

Del Lungo Camiciotti, Gabriella. 2006. From your obedient humble servants to yours faithfully: The negotiation of professional roles in the commercial correspondence of the second half of the nineteenth century. In Marina Dossena \& Irma Taavitsainen (eds.), Diachronic perspectives on domain-specific English, 153-172. Bern: Peter Lang.

Del Lungo Camiciotti, Gabriella. 2012. An atypical commercial correspondence: Negotiating artefacts and status. In Marina Dossena \& Gabriella Del Lungo Camiciotti (eds.), Letter writing in early modern Europe, 105-120. Amsterdam \& Philadelphia: John Benjamins.

$D L C=$ Real Academia Española. 1843. Diccionario de la lengua castellana por la real Academia Española: novena edición. Madrid: Imprenta de D. Francisco María Fernández.

Dossena, Marina. 2010. Building trust through (self-)appraisal in nineteenth-century business correspondence. In Päivi Pahta, Minna Nevala, Arja Nurmi \& Minna Palander-Collin (eds.), Social roles and langauge practices in late modern English, 191-209. Amsterdam \& Philadelphia: John Benjamins.

Eemeren, Frans H. van \& Rob Grootendorst. 1992. Argumentation, communication and fallacies: A pragma-dialectical perspective. London \& New York: Routledge.

Fehr, Beverley Anne. 1996. Friendship processes. Thousand Oaks, CA: Sage Publications.

Fitzmaurice, Susan. 2012. Sociability: Conversation and the performance of friendship in early eighteenth-century letters. In Ulrich Busse \& Axel Hübler (eds.), Investigations into the meta-communicative lexicon of English: A contribution to historical pragmatics, 21-44. Amsterdam \& Philadelphia: John Benjamins.

Galati, Dario, Barbara Sini, Carla Tinti \& Silvia Testa. 2008. The lexicon of emotion in the neoLatin anguages. Social Science Information 47(2). 205-220.

Garrioch, David. 2014. From Christian friendship to secular sentimentality: Enlightenment reevaluations. In Barbara Caine (ed.), Friendship: A history, 165-214. London: Equinox Press.

Guidolin, Gaia. 2011. Analisi linguistica del carteggio di Pietro e Alessandro Verri (1766-1797). Padova: Università degli Studi di Padova PhD thesis.

Halliday, Michael AK \& Christian MIM Matthiessen. 2004. An introduction to functional grammar. London: Arnold.

Haseldine, Julian P. 1994. Understanding the language of amicitia: The friendship circle of Peter of Celle. Journal of Medieval History 20(3). 237-260.

Kádár, Dániel Z. \& Sara Mills. 2013. Rethinking discernment. Journal of Politeness Research: language, behaviour, Culture 9(2). 133-158.

Keightley, Ron. 2005. Garrido to Salvado: Letters from exile. New Norcia Studies 13. 35-41.

Kinder, John J. 2010. The correspondence of Canon Raffaele Martelli in the New Norcia Archives: A first overview. New Norcia Studies 18. 59-67.

Kinder, John J. 2011. "I'm writing simply to say that I have nothing to write about": The Martelli letters, 1854-1864. New Norcia Studies 19. 19-33.

Kinder, John J \& Joshua Brown. 2014. Canon Raffaele Martelli in Western Australia, 1853-1864: Life and letters. Northcote, Vic: Abbey Press. 
Martin, John. 1997. Inventing sincerity, refashioning prudence: The discovery of the individual in Renaissance Europe. American Historical Review 102(5). 1309-1342.

Moreton, Emma. 2015. "I hope you will write": The function of projection structures in a corpus of nineteenth century Irish emigrant correspondence. Journal of Historical Pragmatics 16 (2). 277-303.

Nuova enciclopedia popolare = Nuova enciclopedia popolare ovvero dizionario generale di scienze, lettere, arti, storia, geografia, ecc. ecc. 1841-1848. Torino: Pomba. 14 voll.

Paternoster, Annick. 2019. Politeness and evaluative adjectives in Italian turn-of-the-century etiquette books (1877-1914). In Annick Paternoster \& Susan Fitzmaurice (eds.), Politeness in nineteenth-century Europe, 107-143. Amsterdam: John Benjamins.

Paternoster, Annick. 2015. Cortesi e scortesi Percorsi di pragmatica storica da Castiglione a Collodi. Roma: Carocci.

Poublan, Danièle. 1991. Affaires et passions: Des lettres parisiennes au milieu du XIX ${ }^{\mathrm{e}}$ siècle. In Roger Chartier (ed.), La Correspondance: Les usages de la lettre au XIXe siecle, 373-406. Paris: Fayard.

Rios, Román. 2017. History of the Benedictine mission and abbey 'nullius' of New Norcia, 1943 edition. Edited by Peter Hocking. Reservoir, Vic: Morning Star Publishing.

Rosenwein, Barbara H. 2006. Emotional communities in the early middle ages. Ithaca \& London: Cornell University Press.

Rosenwein, Barbara H. 2010. The political use of an emotional community: Cluny and its neighbors, 833-965. In Damien Boquet \& Piroska Nagy (eds.), Politiques des émotions au Moyen âge, 205-224. Firenze: SISMLE \& Galluzzo.

Scherer, Klaus R. 1988. Facets of emotion: Recent research. New York \& London: Psychology Press.

Scherer, Klaus R. 2005. What are emotions? And how can they be measured? Social Science Information 44(4). 693-727.

Searle, John R. 1969. Speech acts: An essay on the philosophy of language. Cambridge \& New York: Cambridge University Press.

Silver, Allan. 2003. Friendhsip and sincerity. Sozialer Sinn: Zeitschrift Für Hermeneutische Sozialforschung 4(1). 123-130.

Tasca, Luisa. 2002. La corrispondenza 'per tutti': I manuali epistolari italiani tra Otto e Novecento. Passato E Presente 55. 139-158.

Tasca, Luisa. 2004. Galatei: Buone maniere e cultura borghese nell'Italia dell'Ottocento. Firenze: Le Lettere.

$T B=$ Tommaseo, Niccolò \& Bellini, Bernardo. 1865-1879 Dizionario della lingua italiana. Torino Società Unione Tipografico-Editrice.

Tommaseo, Niccolò. 1867. Nuovo dizionario de' sinonimi della lingua italiana. Milano: Vallardi.

Verdina, Federica. 2016. Voicing language: Italian and Italians in the New Norcia archives. New Norcia Studies 23. 25-37.

Verdina, Federica. 2017. The correspondence of Rosendo Salvado to Propagande Fide (18491900): Italian as a language of communication in the nineteenth century Catholic missionary church. Perth: The University of Western Australia PhD thesis.

Walker, ADM. 1978. The ideal of sincerity. Mind 87(348). 481-497.

Williams, Graham. 2010. "trobled wth a tedious discours": Sincerity, sarcasm and seriousness in the letters of Maria Thynne, c. 1601-1610. Journal of Historical Pragmatics 11(2). 169-193. 
Williams, Graham. 2012. "That thought never ytt entered my harte”: Rhetoricalities of sincerity in early modern English. English Studies 93(7). 809-832.

Williams, Graham. 2013. Women's epistolary utterance: A study of the letters of Joan and Maria Thynne, 1575-1611. Amsterdam \& Philadelphia: John Benjamins.

Williams, Graham. 2018. Sincerity in medieval English language and literature. London: Palgrave Macmillan. 